University of Nebraska - Lincoln

DigitalCommons@University of Nebraska-Lincoln

Faculty Publications: Department of Teaching, Department of Teaching, Learning and Teacher Learning and Teacher Education

Education

2017

Contours of Neoliberalism in US Empirical Educational Research

Mardi Schmeichel

Ajay Sharma

Elizabeth Pittard

Follow this and additional works at: https://digitalcommons.unl.edu/teachlearnfacpub

Part of the Curriculum and Instruction Commons, Social and Philosophical Foundations of Education Commons, and the Teacher Education and Professional Development Commons

This Article is brought to you for free and open access by the Department of Teaching, Learning and Teacher Education at DigitalCommons@University of Nebraska - Lincoln. It has been accepted for inclusion in Faculty Publications: Department of Teaching, Learning and Teacher Education by an authorized administrator of DigitalCommons@University of Nebraska - Lincoln. 
Published in Curriculum Inquiry 47:2 (2017), pp. 195-216; doi: 10.1080/03626784.2017.1283592

Copyright (c) 2017 the Ontario Institute for Studies in Education. Published by Routledge/Taylor and Francis. Used by permission.

Published online February 23, 2017.

\title{
Contours of Neoliberalism in US Empirical Educational Research
}

\author{
Mardi Schmeichel, ${ }^{1}$ Ajay Sharma, ${ }^{1}$ and Elizabeth Pittard ${ }^{2}$
}

1. Department of Educational Theory and Practice, College of Education, University of Georgia, Athens, Georgia, USA

2. Department of Early Childhood and Elementary Education, Georgia State University, Atlanta, Georgia, USA

Corresponding author - Mardi Schmeichel, email mardi@uga.edu

\begin{abstract}
Neoliberalism has an enormous influence on $\mathrm{P}-12$ education in most industrial societies. In this integrative, theoretical literature review, we surveyed the journal articles on neoliberalism in US-based educational research to better understand how neoliberalism has been conceptualized in this body of work and to offer implications for future research on neoliberalism and education. We drew on Foucauldian discourse theories to conduct an analysis of peer-reviewed studies of American P-12 contexts to consider how researchers' depictions of neoliberalism have shaped the discourse of neoliberalism in education and contributed to particular ways of thinking and responding to neoliberalism in the United States. The resulting analysis describes the topics addressed in the data, the definitions of neoliberalism presented across the studies, the application of neoliberalism to phenomena, and the depth of attention to neoliberalism in the research. The authors contend that future research must consider and document how historically situated and contradictory elements of a "rascal" discourse like neoliberalism interacts with existing discourses to impact life in ways that subjugate but may also create recuperative spaces for hope and creative resignification.
\end{abstract}

Keywords: neoliberalism, discourse, P-12 education, literature review, educational research

Neoliberalism has been one of the most influential phenomena in industrialized nations for the last three decades. By elevating individualized, market-based competition and 
exchange as the central and most desirable governing principle for organizing human action and social life, even in areas hitherto considered noneconomic, neoliberalism has shaped all aspects of our societies. According to Foucault (2008), neoliberalism arose primarily as a conservative intellectual response to progressive state-led initiatives in the USA and Western Europe in the latter half of the twentieth century. Initially an intellectual movement, led by economists such as Milton Friedman and Friedrich Hayek, neoliberal theorists sought to influence the state and society through advocacy of neoliberal policies across the world. Neoliberalism has had a profound influence on the United States in particular, which has served as a fountainhead of neoliberal discourse for much of the world. Predictably, it has also profoundly impacted US schools and the education they offer (Engel, 2000; Lakes \& Carter, 2011). This influence was noted by education researchers since the outset of the introduction of neoliberal ideas, and over time a corpus of research has accumulated, focused on understanding the different ways neoliberal discourses have shaped $\mathrm{P}-12$ education.

We contend that it is time to look back and take measure of the general contours of research on this issue to get a better sense of the ground covered thus far and to map out possible trajectories for the future. As philosopher Wendy Larner (2000) asserted, the effort to understand how neoliberalism has been deployed is not inconsequential because "our understandings of this phenomenon shape our readings of the scope and content of possible political interventions" (p. 6). In this article, we present a review of the empirical research on neoliberalism in US P-12 education. Given the importance of understanding how profoundly neoliberalism has impacted education, this literature review seeks to explore the dialogue on neoliberalism in empirical research within P-12 schools and classrooms in an effort to better understand some of the key educational issues of our time. From the outset, we decided to exclude broad commentaries on neoliberal influence on education in the USA. This important body of work, which has accumulated thanks to sustained contributions from critical scholars like Pauline Lipman (e.g., 2011, 2013), Michael Apple (e.g., 2006a, 2006b), and Henry Giroux (e.g., 2002, 2004a, 2004b), is predominantly theoretical and has often focused on top-down critiques on topics such as policy, higher education, or broader considerations of how neoliberalism functions within cities, systems, and institutions. While these analyses have made critical contributions to the educational research community's understanding of the ways in which neoliberalism is reshaping US public education, they typically do not explore the experiences of teachers and students whose classrooms are being reshaped by these neoliberal forces or provide closeup examples of how the discourses of neoliberalism have been deployed in education.

Rather than reviewing broad, sweeping discussions of neoliberalism in US education, in this study we were interested in examining how researchers were providing specific accounts of "actually existing" neoliberalism (Brenner \& Theodore, 2002), a term used to describe the local, contextual, embedded product of neoliberal projects. This focus is informed by the understanding of the challenge of defining, identifying, and describing what neoliberalism is, looks, sounds, and feels like in day-to-day existence. In this study, our goal was to understand how researchers who were attempting to describe actually existing neoliberalism engaged in the complex, difficult work of identifying something that has proven notoriously difficult to describe. This focus is important because the complexity of 
describing neoliberalism has given rise to multiple, sometime conflicting, articulations. It is routinely mapped onto all sorts of socioeconomic and political projects, practices, and institutions and has become a sort of "general descriptor for the dominant ideological sensibilities and imperatives of the post-Keynesian globalization era" (James, 2013, p. 31). Scholars in anthropology (e.g., Hilgers, 2013; Jessop, 2013; Wacquant, 2012), geography (e.g., Brenner, Peck, \& Theodore, 2010; Peck, 2013), and political science (e.g., Boas \& GansMorse, 2009), for example, have engaged in dialogue regarding the complexity of defining, identifying, and applying the term "neoliberalism" consistently within the social sciences. The present moment seems to be an appropriate time to review how researchers in education are attending to this challenge in their description of $\mathrm{P}-12$ contexts.

\section{Framing Neoliberalism}

Before beginning our description of the attention to neoliberalism in empirical educational research, we provide a summary of Larner's (2000) framework of the three most prominent ways in which neoliberalism has been conceived, recognized, and analyzed by researchers. Larner's framework is a particularly helpful resource for navigating the challenge of understanding the vast corpus of literature on neoliberalism:

1. Neo-liberalism as policy: In this most common conceptualization, neoliberalism is understood as a policy framework that favors relatively unregulated operation of markets. In analyses that favor such a conceptualization, the main foci appears to be on the governments and institutions and their roles in promoting or resisting policies that scale back the role of the government and position markets as the key mechanisms structuring social life;

2. Neo-liberalism as ideology: Here neoliberalism is generally portrayed as successful in shaping political programs as well as individual subjectivities. According to Larner, many neo-Marxists, socialists, and feminists have sought to understand this success by taking a more sociological approach to neoliberalism. From this perspective, neoliberalism is seen as the hegemonic ideology of the ruling class that has managed to secure the consent of the people, and has constituted their subjectivities in ways that allow for social reproduction and the perpetuation of the dominance of the ruling class;

3. Neo-liberalism as governmentality: This reading of neoliberalism approaches the phenomenon from a poststructural Foucauldian perspective. Following the discursive turn in philosophy and social theory, this interpretation presents neoliberalism as a set of related but inconsistent discursive practices that aim at transferring the locus of governance from the state to the individual such that citizens begin to govern themselves according to a market-based rationality. Foucault (1997) described governmentality as "the governance of the self by oneself in its articulation with relations with others" (p. 88). The important point about neoliberalism as governmentality is that it recasts the social domain as economic and the market as the key mechanism for social exchange. Further, it positions an individual as Homo 
economicus, i.e., as moral, responsible "entrepreneur of himself" (Foucault, 2008 , p. 226) who governs himself by rationally assessing the costs and benefits of an act against other possible alternative acts (Lemke, 2001).

\section{Representing Rascal Neoliberal Discourses}

While we agree that neoliberalism can be glimpsed in policy documents, and marketoriented ideologies regularly carry its imprimatur, in our own work we have found it very useful to see neoliberalism from a Foucauldian discursive lens as described earlier. As discourse analysts, we know that identifying the presence and effect of any discourse is usually a difficult task. We have found it particularly challenging to pin down the discourses of neoliberalism. As Brenner, Peck \& Theodore (2010) assert, over the years neoliberalism has emerged as "a rascal concept-promiscuously pervasive, yet inconsistently defined, empirically imprecise and frequently contested" (p. 184). As such, connecting the effects of a rascal discourse like neoliberalism accurately to specific events or practices in direct correlation is difficult.

Adding additional complexity is that what occurs in the context of schools, as in all social contexts, is shaped by multiple discourses and histories; there is not just one force or one discourse acting on schools, teachers, students, and the communities in which they are located. Further, many of these discourses often lead to similar outcomes, so linking events on the ground back to putatively causal discourses is inherently challenging and often problematic. Nonetheless, as educational researchers, we often have to describe the contexts we study and the behaviors we observe in 8,000 words or less, which can result in the representations of reduced complexity and flattened texture. While this reduction of complexity is not specific to journal-based research on neoliberalism in particular, we contend that the rascal-like nature of neoliberal discourses makes it particularly difficult to represent effectively in this format. Further, we contend that there are significant consequences for failing to represent neoliberalism in a robust way.

Our goal in this study was to understand what is being said about neoliberalism in educational research journals and how the concept is being deployed and contextualized in relation to schooling. In order to achieve this goal, we turned to discourse theories to provide a framework for our research and in particular to help us think about how the educational research community has made particular notions of neoliberalism intelligible. Drawing from these theories, we presume that discourses are groups of utterances that have coherence and force and are produced by particular rules and structures (Mills, 2004). In particular, we adhere to the understanding, following Foucault, that discourses produce and are continuously produced in relations of power, knowledge, and truth. Our understanding of this conception of discourse relies heavily upon the belief that discourses have the potential to produce particular effects while excluding others, an idea perhaps most famously reflected in Foucault's statement that discourses are not merely groups of signs, but "practices that systematically form the objects of which they speak" (1972, p. 54). We take this to mean that discourses are performative; they produce something beyond the words and texts in which they appear.

In this study, we were interested in considering how researchers' depictions of neoliberalism in education-or in other words, their choices to highlight certain aspects of the 
neoliberal phenomena, to focus on specific topics, and to present particular definitions of neoliberalism - has shaped the discourse of neoliberalism in US education and contributed to particular ways of thinking about and responding to neoliberalism in the USA. From our perspective, neoliberalism and the institutions and structures of education are inextricably entangled, but ways of describing that entanglement are not inevitable, fixed, or benign. The choices authors make not only shape how our field might think and react to how neoliberalism is having an impact on education but also constrain our responses. Building on this, our review of the literature was framed by the understanding that through the researchers' descriptions of neoliberalism within education, particular ways of thinking about it as well as material effects on objects and subjects can be reproduced and reinscribed. We want to be careful not to overstate the discursive effects of the relatively small sample of empirical research reviewed in this study, but we contend that analyses of the approaches that have been deployed in research projects such as the ones examined here contribute to a richer and more grounded understanding of neoliberalism and its impact on education.

\section{Methodology and Sample}

In this integrative, theoretical literature review, we surveyed the empirical literature on neoliberalism in United States educational research to better understand how neoliberalism has been conceptualized in this body of work, to determine how these studies extend our understanding of neoliberalism, and to offer implications for future research on neoliberalism and education. With these aims in mind, we began by searching the following four databases: Educational Research Complete (EBSCO), PsychINFO, Web of Knowledge, and ERIC. Our review specifically excluded longer forms of published research such as books and dissertations.

Unique search processes were developed from the available search terms and strategies within each database, but in general, neoliberal* was used as a wild card search term of available descriptors or subjects in the education-focused databases, and neoliberal ${ }^{*}$ and $\mathrm{edu}^{*}$ were used as search terms in the broader databases in order to narrow down the search to education-focused publications searchable as of June 2013. We eliminated duplicates, articles not in English, and articles not about education. This first round of review resulted in 703 articles.

The initial review of these articles indicated that this research described educational contexts in a wide variety of countries from every region of the world. Further, we found that there were noticeable and significant differences in how researchers in different countries saw neoliberalism impacting education within their countries. This realization led us to the decision that focusing on the educational research within one nation would be a natural unit of study for literature review purposes. Our decision to limit our search process to research in the United States is partly based on this reasoning. Further, as indicated in the introduction, another reason for limiting our review to research based in the United Stated is this country's germinal relationship to neoliberalism. We contend that a comprehensive look at how neoliberalism is seen as influencing US education is critical to any research agenda that aims to understand neoliberal influence on our world. 
In the second round of review, at least one author read the abstract of each article to determine, first, if it contained the word neoliberal, and second, if it appeared to describe empirical research conducted in the United States within a P-12 context. This review narrowed the set to 79 articles. Next, each author was assigned a set of articles to more thoroughly review with the purpose of confirming whether each article included significant attention to neoliberalism and described empirical research. In order to focus on articles that would describe actually existing neoliberalism in $\mathrm{P}-12$ contexts, we defined empirical research as studies that described the use and analysis of empirical data (e.g., interviews, observations, documents, etc.) generated for or collected in relation to the project. While it was not imperative that the term "data" be used specifically, we did exclude articles in which authors did not describe the data used in the study in an identifiable manner. This excluded articles in which the approach to describing neoliberalism was predominantly historical and in which researchers drew from an unspecified set of resources to produce a synthesis of neoliberalism's effect on a community or schools in general. This more intensive review of the full texts narrowed the sample to 24 articles. The analysis of research reported in this paper is based on an in-depth critical review of these 24 publications.

Drawing on other reviews of educational literature (e.g., Rogers, Malancharuvil-Berkes, Mosley, Hui, \& O'Garro, 2005), as well as the recent literature reviews of neoliberalism within the field of anthropology (Hilgers, 2013; Jessop, 2013; Wacquant, 2012), we developed an initial codebook to guide our analysis and to create consistency in our review of the data. In the first round of analysis, at least two members of the research team read each of the 24 articles, completed the initial codebook, and wrote a critical summary of each article. Then, in the multiple sessions of analyses, the research team compared and checked the codes and critical summaries for inter-rater reliability. Through these discussions, we established a common "interpretive zone" for collaborative sense-making and recursive identification of emerging patterns (Wasser \& Bresler, 1996). Over the course of several months, we participated in a reiterative cycle of rereading theories of neoliberalism and analyzing data. Through this process, we identified similarities and differences across the articles and determined trends across the data. In the following three sections, we provide a discussion of the resulting themes and findings.

\section{Finding Neoliberalism}

Because there has been such limited empirical research on neoliberalism within education in the USA, it is critical to identify the spheres and topics to which neoliberalism has appeared salient to researchers and to identify how it has become possible to identify it. In our project, we wanted to add to that conversation by identifying where scholars were "finding" neoliberalism. Our review of the studies led us to categorize the articles on two different levels: first, on the basis of what the research used as the primary type of data, and second, based on the topic of the study. ${ }^{1}$ Table 1 presents an overview of both categories. 


\begin{tabular}{lllll}
\hline \multicolumn{2}{l}{ Table 1. Focus of the Analysis } & & \\
\cline { 1 - 1 } \multicolumn{2}{l}{ Studies using texts as data } & & & Studies using participant data \\
\cline { 1 - 1 } \cline { 1 - 1 } Focus of the study & $\#$ & & Focus of the study & $\#$ \\
\hline Speeches & 2 & & Teachers & 6 \\
Standards & 2 & & Students & 2 \\
Curriculum materials & 3 & & Communities & 4 \\
Newspaper articles & 1 & & School districts & 3 \\
Practitioner journal & 1 & & & \\
\hline
\end{tabular}

The articles categorized as "Textual Analysis," which represented more than a third of all the research in the data, varied widely in topic, scope, and methodological approach but shared in common a reliance on written text as the primary data source for analysis. The articles that examined curricular resources (Nadesan, 2006; Petersen, 2009; Sloan, 2008) and standards documents (Beltramo \& Duncheon, 2013; Cauglan \& Beach, 2007) examined texts developed to guide some aspect of student and teacher activity in P-12 classrooms. These studies attempted to identify how the language used in these texts revealed, conveyed, and/or promoted neoliberal ideals and goals. Several researchers collected and analyzed data from more widely circulating sources, including speeches (Hairston, 2013; Suspitsyna, 2010) and newspapers (Hankins \& Martin, 2006). These articles were similar in that researchers sought to identify attempts to shape the public perception of education. Specifically, the studies could be characterized as attempts to reveal the efforts of specific actors to convince the public that market rationalities offer solutions for schools. ${ }^{2}$ While these articles do not examine the effect on readers or listeners, they do seek to explain how the language used in the texts under study promote a neoliberal perspective on education and work to legitimize neoliberal rationality.

These studies make an important contribution because they examine the influence of the discourse of neoliberalism on education, and this is relevant because, as noted in the discussion of discourse theories, how we speak and write about topics has a performative function. Research analyzing the neoliberal discourses in the texts of education or texts about education, therefore, make important contributions to understanding how neoliberalism may be working to produce itself in material ways in educational spaces. Textually oriented research can be very helpful in understanding the nature and scope of the efforts (e.g., Gates Foundation, Walton Foundation, Pearson Education, Business Roundtable) to recast US public education in neoliberal terms and can reveal how neoliberal discourses are being used in an attempt to reshape education primarily as a private good, schools as service providers, and parents as consumers in an educational marketplace.

However, when we look at the direction and source of change that is occurring in education on account of neoliberalism, the textual-focused research of documents may indicate that neoliberal influence originates at the top, where speeches by recent presidents and other federal Department of Education officials, curriculum standards promulgated by state departments of education, or policies by local organizations sanctioning charter schools or private organizations like Teach for America, are being made. We posit that this research can also be problematic when it encourages or does not counter the assumption 
of a direct causal link between speech and observed outcomes. This approach ignores the critical role of other factors, such as intermediaries, intervening socio-spatial layers, local agents, resources, and other discourses in shaping the outcomes (Lingard, 2013; McDermott, Fitzgerald, \& Buchanan, 2013). As a result, textually focused research can run the risk of overstating the influence of hegemonic ideas like neoliberalism.

In contrast to text-focused research, several researchers chose to investigate the effects and traces of neoliberalism in the lived experiences, practices, institutions, and structures on the ground. Review of this research reveals three major foci of analysis: (a) how neoliberalism is influencing education, (b) where this influence can be seen, and (c) what local actors are doing in response to this influence. Researchers interested in knowing how neoliberalism is able to have an impact on education and schools appear to be focused on investigating discourse and school reform efforts as conduits for neoliberalism to enter local contexts and impact education (e.g., Barlett, Frederick, Gulbrandsen, \& Murillo, 2002; Mette, 2013). In terms of areas where neoliberalism is seen to be doing its work, our review indicates that researchers are looking for the footprints of neoliberalism in a few specific directions. These include investigating how neoliberalism is shaping efforts to improve schools (Knoester, 2011) and impacting school/community relationships (Edmondson, 2001). Finally, we found a few researchers who were more interested in exploring what teachers and students were doing in response to the influence of neoliberalism in their lives. These researchers found teachers and students responding in diverse ways to neoliberalism, including elements of co-option as well as creative resignification (Grady, Marquez, \& McLaren, 2012; Picower, 2013). In contrast to the textually based research, the articles that relied on data generated from participants' lived experiences reveal the potential for reaction and response to neoliberal forces. While research describing actors' agency composed a limited proportion of the data set, it is important to acknowledge the potential contribution of this kind of "bottom-up" research and its capacity to foster our understanding of how neoliberalism can be resisted.

\section{Defining Neoliberalism: Marx Rules}

Another aspect of our review included determining to whom authors were turning for their definitions of neoliberalism. In other words, we asked whose definitions of neoliberalism appeared in the articles. To analyze this, we recorded the names of authors quoted or cited in relation to descriptions of neoliberalism in each article. The sections of the articles in which neoliberalism was defined typically appeared in the beginning sections of each paper and varied significantly in length. As a whole, however, these sections were similar in that they introduced the concept of neoliberalism, defined it, and then situated neoliberalism in a context relevant to the topic under study. ${ }^{3}$ In each article, quotations and citations were used to support the explanation of neoliberalism.

We recorded a total of 112 different authors cited in relation to definitions of neoliberalism. While there were a wide variety of authors cited in total, the repetition of four authors in an overwhelming proportion of the articles-David Harvey, David Hursh, Michael Apple, and Henry Giroux - warrants further consideration. References to at least one of these authors' publications appear within 19 different articles: only five articles did not 
reference at least one of these authors. Table 2 breaks down the number of articles citing each author.

\begin{tabular}{lcc}
\hline \multicolumn{3}{c}{ Table 2. Authors Most Cited or Quoted in Descriptions and Definitions of Neoliberalism } \\
\hline Author & \# of articles & Proportion of data set \\
\hline David Harvey & 10 & $42 \%$ \\
David Hursh & 8 & $33 \%$ \\
Michael Apple & 5 & $21 \%$ \\
Henry Giroux & 4 & $17 \%$ \\
\hline
\end{tabular}

Articles citing Hursh, Apple, and Giroux often referred to more than one of those authors' publications. This may be attributable to the fact that Hursh, Apple, and Giroux are scholars of education, and therefore have published multiple journal articles and books that are both germane and accessible to educational researchers. However, nine of the ten Harvey references represented in the chart specifically cite one of his books, A Brief History of Neoliberalism (2005). The over-reliance on this one text as a citation with this data set draws attention to a gap between the contexts of neoliberalism Harvey addresses in Brief History and the field of US education. Further, it may point to some limitations in how education scholars are drawing from outside the field to enrich our understanding of neoliberalism.

Harvey is a professor of geography and, in particular, a scholar of Marxist theories. He has published widely on topics related to political economy, capitalism, and neoliberalism, and much of his scholarship lies outside of the realm of resources typically accessed in traditional educational research. In Brief History, Harvey presents an analysis of the dynamic nature of capital and capitalism, arguing that neoliberalism is a response to the Keynesian welfare state and the expansion of the economic elite's efforts to preserve and advance their material interests. The marketization of education is addressed fleetingly in Brief History, for example, in Harvey's acknowledgment that within neoliberalism, the role of the state is to create markets in domains in which they did not previously exist, "in areas such as land, water, education, health care" (p. 2, italics added).

As such, Harvey's efforts in this book to explain capitalism, globalization, and the actions of nation-states offer a theorization and deployment of neoliberalism that should require a significant amount of work to translate to the world of education in general, or further, to the context of a particular school or classroom. In other words, Harvey is not talking about neoliberalism in a way that is easily translatable to the educational context. To make the connection, for example, between Harvey's discussion of the development of neoliberalism in China or the detailed international economic statistics presented throughout the book and what is happening in schools is not a self-evident transferal of ideas or concepts. We acknowledge that it is not unusual for educational researchers to draw on theories and philosophies outside the field; the discipline has been enriched by a tradition of "borrowing" ideas from noneducation spheres and applying them to the context of schools, students, and teachers. In this case, however, Brief History addresses global political economy at a scale and scope that is significantly broader than any of the studies in the 
data, yet it is the single most used resource to define neoliberalism. Further, Harvey is obviously not the only author outside education publishing about neoliberalism. The prevalence of Harvey's work as a source for the definition of neoliberalism in empirical work examining neoliberalism in US education stands out.

Why is Harvey cited so frequently? While any specific explanation of the references to Harvey's work is beyond the scope of this study, as the single most cited reference within the descriptions of neoliberalism in articles about education, its use as a citational authority in this data set is important to consider. It may be that authors who write about this topic see this reference to Brief History in the educational research literature of those who have published before and use those citations as validation for including it as an acceptable source in their own description of neoliberalism. While the repeated citations reaffirm Harvey's contribution to the analysis of the impact of neoliberalism, most of the authors citing Harvey's work have not clearly explained how they are extending Harvey's critique of neoliberalism to educational contexts in the United States.

The repeated presence of Hursh, Apple, and Giroux's work among the descriptions of neoliberalism is also noteworthy. Like Harvey, these scholars often draw from critical theoretical traditions to build and support their arguments. It is not unusual, for example, to see Marx or scholars whose work builds upon Marx, among the references these authors cite frequently. We draw attention to this not to critique the use of Marxism as a theoretical framework but to point out that this means that there was a heavy reliance upon scholars operating within a critical, Marxist paradigm in defining neoliberalism within the articles in the data set. In other words, the ways in which it is possible to think about neoliberalism may be limited based on the theoretical orientations represented in research about the topic. The preponderance of critical, often Marxist-oriented literature as a source for defining neoliberalism in empirical research is relevant to our analysis because it has implications for what is thinkable within research examining actually existing neoliberalism in P-12 contexts. The discourses we use, or have access to, shape our responses - or as St. Pierre (2000) pointed out, "within the rules of discourse, it makes sense to say only certain things. Other statements and others way of thinking remain unintelligible, outside the realm of possibility" (p. 485). When, as a field, we rely on only one paradigm to theorize up-close, actually existing descriptions of this phenomenon, we are limiting ourselves from thinking about it in other ways.

For example, though poststructuralism has been a key presence in the theoretical map of social science for more than three decades, we found poststructural perspectives underrepresented in the definitions of neoliberalism. Nikolas Rose's $(1992,1993,1996)$ Foucauldian analyses of neoliberalism was cited three times in definitions of neoliberalism, and Foucault's work was cited only once directly. Much of this can perhaps be attributed to the continued dominance of policy-focused research on this topic-an area of research that has long been rather inhospitable to poststructural ideas (Humes \& Bryce, 2003). Nonetheless, the limited appearance of poststructural perspectives to define neoliberalism within empirical, educational research reflects a deficit in the range of perspectives we might have access to in order to think about what neoliberalism is and what it is up to in education. 
For a more complete picture of theoretical perspectives used by researchers in the sample, it is productive to examine the theoretical perspectives used in other areas to understand neoliberalism and its effects. For instance, feminist perspectives have been well used to understand how neoliberalism influences schooling in studies conducted outside of the United States (e.g., Clark, 2009; Watson, 1997), but only one study in our data set drew on feminist theories. And while postcolonialism has been used to investigate the influence of neoliberalism on education in other countries (e.g., Hibbert, Heydon, \& Rich, 2008; Mulinari \& Neegard, 2010), the authors of articles in our data set were found to completely eschew this critical perspective. Further, we did not find any study that explored this topic from perspectives of human development, queer theory, and postfeminism. Also missing from the literature was any mention of the possibility of a postneoliberal vision of society and education. Thus, while scholars and researchers in other regions of the world have started deliberating on alternatives and imagined futures beyond the neoliberal one (HyslopMargison, Emery \& LeBlanc, 2013), such visioning is not evident in the sample we studied in this project.

Derrida (2013) defined trace as the absent part of a sign's presence. He contended that what is present is defined by the abject, as it always leaves a trace of itself in the present. Transposing this insight in our work, we too find that the missing theoretical perspectives haunt and define the field of inquiry with which we are concerned in this review. The exclusion of these perspectives signals a limit, or a discursive boundary, in how neoliberalism has been, and perhaps even how it can be addressed in US educational research. The current corpus is definitely worthy of consideration and valuable for exposing the important structural, and to a smaller extent, poststructural effects of neoliberalization. However, the "present" absences in this field of inquiry tell us that research needs to develop further and come abreast of the current research in social sciences before it is able to offer fresh insights and useful strategies for dealing with consequences of neoliberalism on subjects that find themselves on the margins on subjectivity/identity-related issues of injustice.

\section{The Flattening of Neoliberalism in Empirical Research}

In addition to analyzing the topics of these articles and considering upon what sources authors relied for definitions of neoliberalism, our analysis of the data addressed how neoliberalism was applied in the analysis of the data. In order to develop a more nuanced understanding of how the concept of neoliberalism was applied to the educational context under study in each article, the analysis sections of every study were isolated and evaluated in order to consider how neoliberalism was addressed in relation to the education. Through this analysis, we found multiple examples in which neoliberalism was applied indiscriminately to describe an educational practice or event that seemed to require a more complex explanation. In the following section, we describe an example of this practice in the data and discuss the consequences of its use in neoliberal-focused research in education.

\section{Indiscriminate Application of the Neoliberal Label}

An example of the indiscriminate deployment of neoliberalism is visible through the numerous studies linking accountability measures with neoliberalism. Nineteen of the 24 studies in our data made specific references to "accountability" in education: in all cases, 
these references were linked to neoliberalism in some way. While there were several articles in which the relationships between accountability in the current education regime, the particular contexts under study, and the broader forces of neoliberalism received nuanced, careful attention and detailed explication (e.g., Sloan, 2008; Suspitsyna, 2010; Yang, 2010), in most cases the arguments in the other articles can be characterized as follows: Accountability is neoliberal, so it's reasonable to assume that any reference to it is a sign of neoliberalism in education. Let me show you the different instances in which accountability is showing up in schools. The A-ha! Neoliberalism moment described in these findings-just like much of the attention to other neoliberal tropes like standards, testing, and charter schools-was made possible by mapping a direct relationship between the presence of a current educational phenomenon that researchers want to critique and its relationship to neoliberalism.

While we agree that the intersection(s) of neoliberalism and education are important sites of critique, we assert that the approach described above may make it too easy to observe something like accountability and then explain it in terms of neoliberalism. In these instances, neoliberalism is being used as an indeterminate descriptor that can be slapped onto any unpleasant or unsavory educational practice, policy, or event, a problem that has been recognized by scholars of neoliberalism in other fields. As a consequence of its slipperiness and hybridity, it can be relatively effortless to identify neoliberalism as what Peck termed "the ultimate cause of everything that we don't like" (York Neoliberalism Conference, 2013).

In our field, this is a problem because accountability, like many of the other phenomena labeled as "neoliberal" in the research we reviewed, such as testing, standards, and the influence of the business sector on education, have existed in education for some time. While accountability specifically can indeed be tied to neoliberal discourses, it can also be attached to many other discourses. Back (2012) connects the language of accountability and efficiency in National Council of Teacher Quality (NCTQ) documents to instrumental rationality and not to neoliberalism. Instrumental-technocratic rationality is a discourse that clearly predates and is distinct from neoliberalism (Weber, Roth, \& Wittich, 1978).

As one of the authors of the articles in the data asserts in her historical analysis of the topic, "scholars of education identify several forms of accountability" (Suspityana, 2010, p. 568). For instance, researchers distinguish between market accountability, political accountability, bureaucratic accountability, professional accountability, consumer accountability, and democratic accountability (Ball, Vincent, \& Radnor, 1997; Besley \& Peters, 2006). In addition, moral accountability is also an important attribute in Calvinism-a theology that powerfully impacted the evolution of US schools (Miller, 1997). Accountability practices existed in Western societies long before they were co-opted for neoliberal ends. Clearly, treating accountability as an indication of neoliberalism can be problematic. To label accountability as a solely "neoliberal" phenomenon erases the complexity of both its origins and continued existence in educational spheres.

Our goal in this brief account of the history of Western accountability discourses is not to discount the argument that accountability is related to neoliberalism: accountability is indeed a critical technology of control in neoliberal discourse. However, it can be seen as an indication of neoliberal discourse only if it is shown to be nested in an overall audit regime in education that is governed by an economic grid of intelligibility or when educational 
problems are reduced to the economic problem of finding the most efficient way to allocate scarce resources to reach a desired end.

We draw attention to this indiscriminate application of neoliberalism to phenomena in this research not to discourage researchers from studying the impact of neoliberalism but to encourage the research community to engage explicitly with the considerable messiness of engaging with its rascal qualities. The example described above demonstrated how accountability and neoliberalism are entangled in more complicated ways than has been presented in this research. When the relationship between neoliberalism and the phenomena under description is simplified, neoliberalism is flattened in empirical research. By this, we mean that the complexity of neoliberalism is reduced from a multidimensional, variegated discourse to a one-dimensional force. This, in effect, prevents these studies from engaging with the complex, rascally nature of neoliberalism and addressing its conflicting, contradictory and hybrid articulations. As such, this flattening of the research limits the potential of this research to fully address or critically examine the effects of neoliberalism on students, teachers, schools, and communities at this moment in time.

Clearly, researchers studying neoliberalism face a significant challenge in any effort to tease apart the many different factors that may shape the neoliberal phenomena under study. Even when researchers acknowledge this in their analysis, we can see that it is not easy to hold up something a participant says or does as solely neoliberal. This challenge was clearly illustrated by the handful of researchers in the articles we reviewed who did attempt to provide a more nuanced definition of what counted as neoliberal in their analysis of the data. For example, in their ethnographic study, Demereth, Lynch, and Davidson (2008) followed four high-achieving high school students over four years to explore what they labeled the "construction of advantage" in the United States. The researchers were particularly interested in understanding how students constructed their identities in relation to the demands and stresses of education and employment "markets" shaped by neoliberalism. The authors observed of their student participants: "Work ethics are nothing new, but the degree to which these young people rationalize them and self-consciously cultivate them, may be" (p. 284). Although acknowledging that work ethics and other qualities, like competitiveness, are not recent phenomena, the analyses of student comments and perceptions in this study is an example of the messy work of distinguishing what role neoliberalism plays in shaping students' notions of identity.

Another brief example of this can be seen in a footnote from Hankin and Martin's (2006) textual analysis of charter school rhetoric in the Atlanta Journal Constitution newspaper. Their opening argument that charter schools are "a neoliberal shift in education" includes a footnote that begins with the following statement: "We don't wish to suggest that all challenges to traditional, state-structured education are inherently neoliberal" (p. 529). This comment acknowledges the complexity of labeling any event as a "neoliberal" one-even something as commonly associated with neoliberalism as charter schools. Rather than appearing as a footnote, however, it is critical that researchers include these types of markers in their analyses and commentaries in order to insure that everything under the sun does not get swept under the umbrella of neoliberalism.

One article focusing on what the author specifically labeled "actually occurring" neoliberalism in school garden programs provides a more robust example of the kind of nuanced 
approach we think is necessary. In this article, Hayes-Conroy (2010) makes a point to question whether what she is describing reflects neoliberalism or not. For example, she notes that "it is not clear that a focus on local, school-based food sources teaches students to shift the onus of responsibility away from the state" (p. 80) and that "a turn away from the state does not necessarily or only mean a turn towards neoliberalism in either ideology or practice" (p. 82). After describing the historical distrust of the government in the African-American community in Berkeley, she argued "it would be a vast generalization to suggest that a turn away from the state necessarily indicates a turn toward neoliberalism" (p. 86). Further, she addressed directly the methodological complexity of researching neoliberalism, noting that what the participants articulated in interviews and observations "cannot possibly be one thing ... whether 'neoliberal' or 'anticapitalist'" (p. 72). This study is an example of how researchers might complicate rather than simplify notions of neoliberalism and present nuanced arguments around how neoliberalism might be explored in specific, local contexts.

Further, Hayes-Conroy's analysis demonstrates that it is imperative to acknowledge that other discourses besides neoliberalism do exist in education-today as well as in the past. Where there appears to be some overlap, we have a responsibility to explore how these previously circulating discourses may have been co-opted by neoliberalism as we seek to understand how the discourses may be working together as well as how they may contradict one other. This speaks to another issue that we describe next as the flattening of neoliberalism in its application in this data, through the absence of attention to history and other discourses in the description of the phenomena under study.

\section{Acknowledging History and Other Discourses}

Although several articles (e.g., Tobin, 2011) acknowledged the philosophical or historical origins of neoliberalism, across the data as a whole there was an alarming absence of effort to situate phenomena identified as neoliberal within any kind of historical context. For example, if the studies included references to the influence of business on education, there was rarely any acknowledgment that business and education have long-established relationships, but that these relationships began to change as neoliberal discourses and policies gained momentum in the United States in late 1970s. Instead, most of these studies often presented business/education relationships as if they were created solely for the purposes of achieving neoliberal ends. While the increased intensity of business/education relationships is an important aspect of understanding neoliberalism's influence on schools, the late twentieth century does not mark the first occurrence of big business's attempt to gain influence or control over education policy; historians of education have provided robust accounts of business interest in education that date back to at least the 1880s (see Shipps [2000] for an overview of the historical literature on corporate influence on education). As such, articles in the data that described the relationship between business and schools as something new were ahistorical.

While it is possible that the absence of robust historical analysis reflects our choice to exclude articles that focused primarily on historical accounts of neoliberalism, we argue that empirical studies should not be exempted from situating the historicity of the phenomena they describe. While educational research in general may be plagued by the failure 
to place topics under study in a rich historical context, framing business interest in education as if it had no history prior to the onset of neoliberalism flattens neoliberalism in ways that has real consequences. This flattening contributes to the impression that neoliberalism is a force that has somehow independently created practices in spaces in which they did not exist before. This is not only inaccurate, but it also misses an important opportunity to draw attention to the rhizomatic, assimilative nature of neoliberal discourse.

As Peck (2013) explained, neoliberalism is inherently parasitical, living off preexisting ideologies and discourses. It is critical that we understand how neoliberalism works with other discourses in order to appear commonsensical and convincing. Tying practices like testing and accountability to neoliberalism alone is both ahistorical and ineffective. We need to understand how neoliberalism attaches itself to preexisting discourses to make sense and to appear to be reasonable and rational. ${ }^{4}$ Further, because many of the articles we analyzed do not acknowledge that there are other forces beyond neoliberalism shaping schools, they give the impression that neoliberalism is the only force shaping what is happening in schools today. Strengthening this perception makes it difficult to identify efficacious responses to neoliberalism.

While most of the articles we examined can be widely characterized as attempting to apply neoliberalism in ways that position it as the sole force acting on a particular educational practice, it is important to note that there were a few articles that associated it with other theorized or lived aspects of the social world. In these articles, neoliberalism was identified as one discourse among others acting on the phenomenon under study, and authors worked to show how neoliberal discourses worked with these discourses to insidious ends. For instance, several papers linked neoliberalism with the experience and existence of racism in US schools (e.g., Barlett et al., 2002; Hairston, 2013; Journell, 2011). There were also a few papers that situated neoliberalism within a wider class project aimed at perpetuating the dominance of economic elites over others (e.g., Picower, 2013; Weis \& Fine, 2012). Finally, Schmeichel's (2011) study of a practitioner journal also points to the intersection of discourses through its use of Nancy Fraser's (2009) argument regarding the coopting of feminism by neoliberalism in the 1980s and 1990s as a framework for analysis.

\section{Neoliberalism as a Backdrop}

As described in the previous section, the articles reviewed for this project applied neoliberalism in a variety of ways. Another observable variation in the sample was the level of engagement with the topic of neoliberalism within the analysis. Although we initially used open-ended search descriptors to identify articles, we determined in later rounds of analysis that the word neoliberalism must appear in both the abstract and the text for the article to be included in the final sample. While this excluded many texts in which the topic of neoliberalism was not addressed robustly, the decision to include only the articles with significant attention to neoliberalism was more difficult to quantify, as what counts as significant attention was difficult to establish across a data set in which neoliberalism was addressed in such divergent ways.

In the six articles described in this section, we determined that there was significant attention to neoliberalism at some point in the article-typically in the setup of the problem or phenomena under study - but almost no attention to neoliberalism in the analysis of the 
data. For example, it was typical in these articles for the word "neoliberalism" to appear only once or twice-or not at all-in the discussion of the data, despite sometimes quite extensive attention to the topic in the abstract and introductory pages of the study description. Thus, while at first glance these studies may appear to be about neoliberalism in education on the basis of the presence of the term in the title, the abstract, or in the number of times the word is used in the text, the bulk of analysis described in the study failed to make specific connections between the topic under examination and neoliberalism. In four of these six studies, neoliberalism was mentioned again in the conclusion, albeit fleetingly in three out of four instances.

There could be several possible explanations for this pattern in the data. As discussed throughout this article, neoliberalism is a slippery, rascal discourse; it has significant effects on education, but they are difficult to identify specifically. This makes it a convenient bogeyman to tack on to any study. Further, including references to neoliberalism in a study is perhaps a way to demonstrate its relevance, and for authors to demonstrate that they are aware of the current issues facing education. But this kind of cursory inclusion in a significant proportion of the only articles identifiable as using empirical methods to study neoliberalism in US education contexts has several consequences that must be considered. First, it does not contribute to a repository of examples of how to analyze data to identify and understand how neoliberalism is at play. Further, it may give the impression that neoliberalism is being addressed more often and thoroughly than it is. Finally, it contributes to the sense that neoliberalism is everywhere, affecting everything.

\section{Conclusion}

A search for how many times the word neoliberalism has appeared in books written in the English language since 1800 on Google Ngram Viewer (which charts the frequency of words and phrases appearing in digital texts) shows a gradual increase after 1980 and a sharp upturn after 1990. It is clear that the scholarly world is interested in understanding neoliberalism and its impact on the world in recent decades. Clearly there is much to be learned about how neoliberalism is having an impact on schools in what is arguably the most neoliberal nation in the world. While the impact of the research in our sample of 24 articles examining actually existing neoliberalism in P-12 US contexts should not be exaggerated, the trends we saw have much to tell us about the challenge of describing how neoliberalism is expressed, produced, and embedded in particular contexts (Brenner \& Theodore, 2002) and indicate some fruitful directions for future research.

From our Foucauldian perspective, neoliberalism functions as a discourse of governmentality that restructures individual and collective life on an economic rationality and promises to serve the utilitarian goal of maximizing societal prosperity and the libertarian objective of securing individual freedoms and liberty. As a global discourse, neoliberalism not only describes the world but also produces it for us. However, in educational contexts, just as in other contexts, it often circulates alongside other discourses with similar representative and productive powers in a contingent and dynamic order of discourse (Fairclough, 2003). Therefore, while in many contexts neoliberalism may be the dominant discourse and thus most influential in discursive acts of representation and production of 
the social world, in other contexts it circulates only as a marginal discourse. Given the putative importance of neoliberal influence on education, it is imperative that we test this assumption through empirical research in educational contexts.

As our literature review of the topic indicates, almost half of the empirical research on actually existing neoliberalism in US P-12 contexts was limited to exploring the nature and extent of neoliberal influence on textual representations. The importance of textual research cannot be denied, as texts both reflect and constitute our social world. The textual examples we reviewed demonstrated that the influence of neoliberalism in shaping policy and other influential documents is considerable and may only increase in the future. However, the role of discourses in constituting or having an impact on life in actual lived contexts cannot be assumed simply on the basis of their existence in texts. Discourses need supportive material, structural, and institutional conditions before they are able to circulate and have an impact on social life in local contexts (Weedon, 1987). After all, in the United States, neoliberalism lingered as an academic discourse in philosophical texts for many decades before it was taken up by the economic-political elite and put into circulation in US social life to legitimize their material interests.

Unfortunately, our review showed that empirical research that explores how neoliberalism is having an impact on local educational contexts is inadequate. If neoliberalism as a discourse is circulating and influencing schools, teachers, and students in classrooms and beyond, we need to understand how that happens in different local contexts through rigorous empirical research. This is important because without a strong body of empirical research, the discourse about neoliberalism and education will continue to remain overwhelmingly conceptual and speculative, and thus run the risk of overstating or mischaracterizing the influence of neoliberalism upon the daily lives of individuals.

Another problem we identified in the empirical educational research was the lack of attention to the interaction of neoliberalism with other discourses. Researchers outside of education have argued that neoliberalism exists alongside many other discourses in relationships that are messy, entangled, and locally contingent (Peck, 2013). This is not to say that US education scholars have not recognized the relationship between neoliberalism and other discourses, like racism. Pauline Lipman (2013) for example, has specifically identified the entanglement of race and neoliberalism in her work. However, few of the empirical studies we reviewed paid significant attention to the multiple discourses that produce what becomes possible in the everyday lived experiences of those working on the ground in education. Perhaps portrayals of neoliberalism as an ahistorical, hegemonic, and monolithic actor in education can be advantageous in creating a recognizable common enemy that activists all over the world can rally against. However, a more nuanced look at neoliberalism's entangled coexistence with influential discourses in education is critical both for research and long-term political goals. We acknowledge the difficulty in attempting to "pin down" any discourse, particularly a discourse as rhizomatic as neoliberalism. But it is only through empirical research of neoliberalism-at-work amid messy real-life situations that we can hope to have a detailed understanding of its diverse instantiations in lived experiences of students, teachers, and other stakeholders in public education.

While there was extensive attention to textual analysis, it is important to note the encouraging presence of a small group of researchers who chose to look for effects of neoliberalism 
on the ground in diverse local contexts (e.g., Demereth et al., 2008; Hayes-Conroy, 2010). Further, rather than showing local participants as passive and helpless against the productive power of neoliberalism, some of these studies showed that people act with agency to respond to neoliberal influence in diverse creative ways (e.g., Costigan, 2013; Picower, 2013). This kind of research deserves circulation and replication so that educators and researchers can understand that hegemony of any discourse can never be complete and improve their capacities to recognize the spaces for creative and agentive resignification and response in their own local contexts. Similar arguments have been forwarded by cultural theorists Ernest Laclau (2000) and Judith Butler (2000). Unless we see this kind of creative, improvised, bottom-up effort by local actors happening successfully in several local contexts, and write about it in empirical research, it will be difficult to see research literature as a space for finding ways to stitch together local struggles to create a collective democratic response to neoliberalism.

According to Tight (2008), higher education research resembles "a series of, somewhat overlapping, communities of practice" that exhibit relationships of mutuality and share a common resource of knowledge and conceptual tools (p. 604). In our review, we found that empirical research on neoliberalism on education in the United States constitutes one such community of practice, in that we identified more repetitive displays of resource sharing, co-citation, and bibliographic coupling than what would likely be found in more mature and extensive research fields. For example, only a few researchers in education, such as Michael Apple and David Hursh, were heavily cited for articulations of neoliberalism.

The dominance of Marxist and Neo-Marxist interpretations of neoliberalism shape the grid of intelligibility in this small community of practice, with obvious implications for our understanding of what precisely is neoliberalism. There was a paucity of poststructural perspectives on neoliberalism and an almost complete absence of other influential and critical perspectives, such as feminism, postcolonialism, and queer theory. This lack of a diverse range of theoretical perspectives to interpret neoliberalism in research that focuses on describing actually existing neoliberalism marks the research space in problematic ways. We acknowledge that our methodological decisions to exclude "nonempirical" literature on neoliberalism, to focus specifically on research conducted on P-12 contexts, and to exclude publications like books and dissertations, eliminated richly theorized work from our analysis. As a result, our findings represent only a corner of the portrait of the use of theory within neoliberal research in the USA. However, we argue that empirical work that describes actually existing neoliberalism in journal articles should be richly theorized and draw from a variety of theoretical traditions. Given the widespread pessimism regarding our ability to respond to neoliberalism (Fisher, 2009; Gibson-Graham, 2006), it is critically important that hitherto marginalized interpretations of neoliberalism are given due attention for the viable alternative futures that may well be lurking there.

Political economist and geographer Jamie Peck argued that neoliberalism remains "an ambiguous, contentious, 'big picture' concept" because some scholars see "its traces and influences everywhere" (2013a, p. 732). From the review of this literature, it appears that many educational researchers conducting empirical research also harbor this notion of neoliberalism as they sought to unproblematically attach descriptions of neoliberalism onto 
all kinds of phenomena and practices within education. As we argued, this haphazard application of neoliberalism is unhelpful for several reasons.

It is clear that education researchers are beginning to recognize the increasing prominence of neoliberalism as a critical part of the educational landscape in the United States. We see this trend reflected in the use of neoliberalism as a backdrop to diverse educational issues. What is interesting in such studies, and in fact in all the papers we reviewed, is the universal characterization of neoliberalism as a negative influence on US education. In this respect, educational research aligns well with the rest of the social science research community in which neoliberalism has also acquired a normative negative connotation (Boas \& Gans-Morse, 2009). Such a portrayal is quite a change of fortunes for a philosophy that began as a positive and well-meaning moderate revision of classical liberalism. Perhaps this transformation is an unintended outcome of the cooptation and (mis)use of neoliberalism by the economic elite to legitimize their material interests.

Empirical research on neoliberalism in the context of $\mathrm{P}-12$ education in the United States is relatively new and underdeveloped, and thus its portrait of neoliberalism should be seen as rough, emergent, and unfinished. While we may not agree with all of the choices made by these authors in their descriptions of actually existing neoliberalism in education, there is no doubt that attention to neoliberalism in schooling is a paramount issue of our times. It will continue to be more critical than ever for justice-oriented researchers to continue to investigate this rascal concept and map new ways to resist its multiple and complex manifestations within education. Given that the majority of studies in our original search indicated that most research on neoliberalism have taken place outside the US context, it is of particular importance that researchers in the USA be exposed to and engage with the ideas described in this study. In time, this body of research will surely develop and mature. Therefore, there is no reason to believe that it will not shine a light on specific manifestations of neoliberalism, contribute to a deeper and richer theoretical understanding of this phenomenon, and last but not the least, point to more just and democratic alternative futures to the "neoliberal" present.

\section{Notes}

1. Some of the articles include descriptions and discussions of multiple forms of data and topics: in these cases, we categorized the study by the type of data or topic that received the most attention.

2. We deliberated extensively about whether textual studies of documents other than curricular materials and standards met our criteria for inclusion, but ultimately chose to include them in our analysis because they: (1) focused on P-12 schools rather than higher education, (2) described how data was used and analyzed, and (3) focused on attempting to describe specific instances of how the discourses of neoliberalism had been deployed in particular contexts.

3. There was one article in the data in which neoliberalism was not defined.

4. This is particularly important in terms of understanding how the neoliberal practices in education have been sold as common-sense solutions to constituents outside of the education community.

Disclosure statement - No potential conflict of interest is reported by the authors. 


\section{References}

Apple, M. (2006a). Understanding and interrupting neoliberalism and neoconservatism in education. Pedagogies, 1(1), 21-26.

Apple, M. (2006b). Educating the 'right' way: Markets, standards, God and inequality. New York: Taylor \& Francis.

Back, S. (2012). Preparing (pseudo) professional. In S. Back (Ed.), Ways of learning to teach (pp. 101128). Rotterdam: Sense.

Ball, S. J., Vincent, C., \& Radnor, H. (1997). Into confusion: LEAs, accountability and democracy. Journal of Education Policy, 12(3), 147-163.

Barlett, L., Frederick, M., Gulbrandsen, T., \& Murillo, E. (2002). The marketization of education: Public schools for private ends. Anthropology \& Education Quarterly, 33(1), 5-29.

Beltramo, J. L., \& Duncheon, J. C. (2013). Globalization standards: A comparison of U.S. and nonU.S. social studies curricula. Journal of Social Studies Research, 37(2), 97-109.

Besley, A. C., \& Peters, M. (2006). Neoliberalism, performance and the assessment of research quality. South African Journal of Higher Education, 20(6), 814-832.

Boas, T., \& Gans-Morse, J. (2009). Neoliberalism: From new liberal philosophy to anti-liberal slogan. Studies in Comparative International Development, 44(2), 137-161.

Brenner, N., Peck, J., \& Theodore, N. I. K. (2010). Variegated neoliberalization: Geographies, modalities, pathways. Global Networks, 10(2), 182-222. doi: 10.1111/j.1471-0374.2009.00277

Brenner, N., \& Theodore, N. (2002). Cities and the geographies of "actually existing" neoliberalism. Antipode, 34(3), 349-379.

Butler, J. (2000). Restaging the universal. In J. Butler, E. Laclau, \& S. Zizek (Eds.), Contingency, hegemony, universality (pp. 11-43). London: Verso.

Caughlan, S., \& Beach, R. (2007). Fissures in standards formulation: The role of neoconservative and neoliberal discourses in justifying standards development in Wisconsin and Minnesota. Education Policy Analysis Archives, 15(18), 1-62.

Clark, S. (2009). A good education: Girls' extracurricular pursuits and school choice. Gender and Education, 21(5), 601-615.

Costigan, A. (2013). New urban teachers transcending neoliberal educational reforms: Embracing aesthetic education as a curriculum of political action. Urban Education, 48(1), 116-148.

Demereth, P., Lynch, J., \& Davidson, M. (2008). Dimensions of psychological capital in a U.S. suburb and high school: Identities in neoliberal times. Anthropology E Education Quarterly, 39(3), 270-292.

Derrida, J. (2013). Of grammatology. (G. C. Spivak, Trans.) Baltimore: Johns Hopkins University Press.

Edmondson, J. (2001). Prairie town: Rural life and literacies. Journal of Research in Rural Education, $17(1), 3-11$.

Engel, M. (2000). The struggle for control of public education. Philadelphia: Temple University Press.

Fairclough, N. (2003). Analysing discourse: Text analysis for social research. London: Routledge.

Fisher, M. (2009). Capitalist realism: Is there no alternative? Hants: O Books.

Foucault, M. (1972). The archeology of knowledge and the discourse on language (A. M. Sheridan Smith, Trans.). New York: Pantheon. (Original work published 1969).

Foucault, M. (1997). Subjectivity and truth. In P. Rabinow (Ed.), Ethics: Subjectivity and truth (pp. 8792). New York: New Press.

Foucault, M. (2008). The birth of biopolitics (G. Burchell, Trans). New York: Picador. (Original work published 1979). 
Fraser, N. (2009). Feminism, capitalism, and the cunning of history. New Left Review, 56, 97-117.

Gibson-Graham, J. K. (2006). The end of capitalism (as we knew it) (2nd ed.). Minneapolis: University of Minnesota Press.

Giroux, H. (2002). Neoliberalism, corporate culture, and the promise of higher education: The university as a democratic public sphere. Harvard Educational Review, 72(4), 425-464.

Giroux, H. (2004a). The terror of neoliberalism: Authoritarianism and the eclipse of democracy. Herndon: Paradigm.

Giroux, H. (2004b). Proto-fascism in America: Neoliberalism and the demise of democracy. Bloomington: Phi Delta Kappa Educational Foundation.

Grady, J., Marquez, R., \& McLaren, P. (2012). A critique of neoliberalism with fierceness: Queer youth of color creating dialogues of resistance. Journal of Homosexuality, 59, 582-1004. doi: 10.1080/00918369 .2012 .699839

Hairston, T. (2013). Continuing inequity through neoliberalism: The conveyance of white dominance in the educational policy speeches of President Barack Obama. Interchange, 43, 229-244. doi: 10.1007/s10780-013-9180-4

Hankins, D., \& Martin, D. (2006). Charter schools and urban regimes in neoliberal context: Making workers and new spaces in metropolitan Atlanta. International Journal of Urban and Regional Research, 30(3), 528-547.

Harvey, D. (2005). A brief history of neoliberalism. Oxford: Oxford University Press.

Hayes-Conroy, J. (2010). School gardens and 'actually existing' neoliberalism. Humboldt Journal of Social Relations, 33(1-2), 64-96.

Hibbert, K., Heydon, R., \& Rich, S. (2008). Beacons of light, rays, or suncatchers? A case study of the positioning of literacy teachers and their knowledge in neoliberal times? Teaching and Teacher Education, 24(2), 303-315.

Hilgers, M. (2013). Embodying neoliberalism: Thoughts and responses to critics. Social Anthropology, 21(1), 75-79.

Humes, W., \& Bryce, T. (2003). Post-structuralism and policy research in education. Journal of Education Policy, 18(2), 175-187.

Hyslop-Margison, E. J., \& LeBlanc, S. (2013). Post-neoliberalism, education, and the principles of democratic learning. In W. Hare \& J. P. Portelli (Eds.), Philosophy of education: Introductory readings (pp. 182-196). Edmonton: Brush Education.

James, M. (2013). Neoliberal heritage redress. In J. A. Henderson \& P. Wakeham (Eds.), Reconciling Canada: Critical perspectives on the culture of redress (pp. 31-62). Toronto: University of Toronto Press.

Jessop, B. (2013). Putting neoliberalism in its time and a place. A response to the debate. Social Anthropology, 21(1), 65-74.

Journell, W. (2011). Teaching the 2008 Presidential election at three demographically diverse schools: An exercise in neoliberal governmentality. Educational Studies, 47, 133-159.

Knoester, M. (2011). Is the outcry for more pilot schools warranted? Democracy, collective bargaining, deregulation, and the politics of school reform in Boston. Educational Policy, 25(3), 387-423.

Laclau, E. (2000). Identity and hegemony. In J. Butler, E. Laclau, \& S. Zizek (Eds.), Contingency, hegemony, universality (44-89). London: Verso.

Lakes, R., \& Carter, P. (2011). Neoliberalism and education: An introduction. Educational Studies, $47(2), 107-110$.

Larner, W. (2000). Neo-liberalism: Policy, ideology, governmentality. Studies in Political Economy, 63, $5-25$. 
Lemke, T. (2001). "The birth of bio-politics": Michel Foucault's lecture at the Collége de France on neo-liberal governmentality. Economy and Society, 30(2), 190-207. doi: 10.1080/03085140120042271

Lingard, B. (2013). The impact of research on education policy in an era of evidence-based policy. Critical Studies in Education, 54(2), 113-131.

Lipman, P. (2011). Neoliberal education: Restructuring dangers and opportunities of the present crisis. Monthly Review, 63(3), 114-127.

Lipman, P. (2013). The new political economy of urban education: Neoliberalism, race, and the right to the city. New York: Routledge.

McDermott, A. M., Fitzgerald, L., \& Buchanan, D. A. (2013). Beyond acceptance and resistance: Entrepreneurial change agency responses in policy implementation. British Journal of Management, 24, S93-S115.

Mette, I. (2013). Turnaround as reform: Opportunity for meaningful change or neoliberal posturing. Interchange, 43, 317-342. doi: 10.1007/s10780-013-9181-3

Miller, R. (1997). What are schools for? Holistic education in American culture. Brandon: Holistic Education.

Mills, S. (2004). Discourse. Oxford: Routledge.

Mulinari, D., \& Neergaard, A. (2010). The "others" in Sweden": Neoliberal policies and policies of "race" in education. Journal for Critical Education Policy Studies, 8(2), 130-164.

Nadesan, M. (2006). The MYD panopticon: Neo-liberalism, governmentality and education. Radical Pedagogy, 8(1), 11.

Peck, J. (2013). Explaining (with) neoliberalism. Territory, politics, and governance, 1(2), 132-157. doi: 10.1080/21622671.2013.785365

Petersen, J. (2009). Media as sentimental education: The political lessons of HBO's The Laramie Project and PBS's Two Towns of Jasper. Critical Studies in Media Communication, 26(3), 255-274.

Picower, B. (2013). Education should be free! Occupy the DOE! Teacher activists involved in the Occupy Wall Street movement. Critical Studies in Education, 54(1), 44-56. doi: 10.1080/17508487.2013 .739569

Rogers, R., Malancharuvil-Berkes, E., Mosley, M., Hui, D., \& O'Garro, J. (2005). Critical discourse analysis in education: A review of the literature. Review of Educational Research, 75(3), 365-416. doi: 10.3102/00346543075003365

Rose, N. (1992). Governing the enterprising self. In P. Heelas \& P. Morris (Eds.), The values of the enterprise culture: The moral debate (pp. 141-164). New York: Routledge.

Rose, N. (1993). Government, authority and expertise in advanced liberalism. Economy and Society, 22, 283-299.

Rose, N. (1996). Governing 'advanced' liberal democracies. In A. Barry, T. Osborne, \& N. Rose (Eds.), Foucault and political reason: Liberalism, neo-liberalism and the rationalities of government (pp. 37-44). Chicago: University of Chicago Press.

Schmeichel, M. (2011). Feminism, neoliberalism, and social studies. Theory and Research in Social Education, 39(1), 6-31.

Shipps, D. (2000). Echoes of corporate influence: Managing away urban school troubles. In L. Cuban \& D. Shipps (Eds.), Reconstructing the common good in education: Coping with intractable American dilemmas (pp. 82-105). Stanford: Stanford University Press.

Sloan, K. (2008). The expanding educational services sector: Neoliberalism and the corporatization of curriculum at the local level in the US. Journal of Curriculum Studies, 40(5), 555-578. 
St. Pierre, E. A. (2000). Poststructural feminism in education: An overview. International Journal of Qualitative Studies in Education, 13(5), 477-515.

Suspitsyna, T. (2010). Accountability in American education as a rhetoric and a technology of governmentality. Journal of Education Policy, 25(5), 567-586.

Tight, M. (2008). Higher education research as tribe, territory and/or community: A co-citation analysis. Higher Education, 55(5), 593-605.

Tobin, K. (2011). Global reproduction and transformation of science education. Cultural Studies of Science Education, 6, 127-142. doi: 10.1007/s11422-010-9293-3

Wacquant, L. (2012). Three steps to a historical anthropology of actually existing neoliberalism. Social Anthropology, 20(1), 66-79.

Wasser, J. D., \& Bresler, L. (1996). Working in the interpretive zone: Conceptualizing collaboration in qualitative research teams. Educational Researcher, 25(5), 5-15.

Watson, S. (1997). Single-sex education for girls: Heterosexuality, gendered subjectivity, and school choice. British Journal of Sociology of Education, 18(3), 371-383.

Weber, M., Roth, G., \& Wittich, C. (1978). Economy and society: An outline of interpretive sociology. Berkeley: University of California Press.

Weedon, C. (1987). Feminist practice and poststructural theory. Oxford: Blackwell.

Weis, L., \& Fine, M. (2012). Critical bifocality and circuits of privilege: Expanding critical ethnographic theory and design. Harvard Educational Review, 82(2), 173-201.

Yang, K. W. (2010). Rites to reform: The cultural production of the reformer in urban schools. Anthropology \& Education Quarterly, 41(2), 144-160. doi: 10.1111/j.1548-1492.2010.01075.x

York Neoliberalism Conference. (2013, August 14). Jamie Peck-"Explaining (with) Neoliberalism" [Video file]. Retrieved from https://www.youtube.com/watch?vD0NSskq9rbYU

\section{Notes on contributors}

Dr. Mardi Schmeichel is an assistant professor in the Department of Educational Theory and Practice in the College of Education and affiliate faculty in the Institute of Women's Studies at the University of Georgia. Her research interests focus on the examination of neoliberalism and gender across a variety of educational contexts and the impact of sports culture on education.

Dr. Ajay Sharma is an associate professor in the Department of Educational Theory and Practice at the University of Georgia, Athens. His research centers on theoretical and ethnographic explorations of neoliberalism's impact on education and implications of climate change for science education. Email ajay@uga.edu

Dr. Elizabeth Pittard is a clinical assistant professor at Georgia State University. She draws from poststructural and feminist theories to examine the working lives of women elementary school teachers, teacher education, and the manifestations of neoliberalism in education. Email bethpittard@ gmail.com 